\title{
Gliomatosis cerebri mimicking viral encephalitis in a 4-year-old child
}

\author{
Mark William McCusker, ${ }^{1}$ Mary Aoife McDonald, ${ }^{2}$ Seamus Looby, ${ }^{1}$ Mary King ${ }^{2}$
}

\section{Correspondence to} Dr Seamus Looby, seamuslooby@beaumont.ie

Accepted 16 March 2014

\section{${ }^{1}$ Department of
Neuroradiology, Beaumont \\ 1 Department of
Neuroradiology, Beaumont Hospital, Dublin, Ireland ${ }^{2}$ Department of Neurology, Temple Street Children's University Hospital, Dublin, Ireland .}

CrossMark

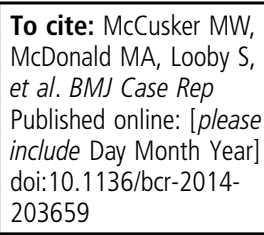

\section{DESCRIPTION}

A 4-year-old boy presented with an afebrile right-sided focal seizure. MRI of the brain demonstrated an infiltrating fluid attenuated inversion recovery (FLAIR) hyperintense abnormality in the left frontal, temporal and occipital white matter, involving the temporal lobe cortex, without enhancement, microhaemorrhage or diffusion restriction (figure 1).

The findings were interpreted as infectious encephalitis and intravenous acyclovir was started. Cerebrospinal fluid analysis revealed normal protein and white cell count, and was negative for viral, bacterial and mycobacterial agents.

After initial improvement the focal seizures recurred. Repeat imaging after 28 days showed progression of the FLAIR abnormality with extension into both thalami (figure 2). The lesion was biopsied and histology showed diffusely infiltrating grade III astrocytoma. The patient was treated with radiotherapy but died 6 months later.

Gliomatosis cerebri (GC) is an infiltrating glial tumour involving at least three cortical lobes. ${ }^{1}$ Presentation in children is uncommon: to our knowledge only eight cases in children younger than 5 years have been described. ${ }^{1-3}$ It typically presents with non-specific symptoms and signs including seizures, hemiparesis, ataxia, lethargy and symptoms of intracranial hypertension. ${ }^{1}{ }^{2} \mathrm{GC}$ may mimic more common disorders, such as encephalitis and acute disseminated encephalomyelitis, resulting in delay in diagnosis and treatment. ${ }^{4}{ }^{5}$ Although prognosis is poor and GC is universally fatal, ${ }^{1}{ }_{2}^{2}$ there is evidence that treatment confers some short-term survival benefit. ${ }^{1}$ It is important, therefore, to include GC in the differential diagnosis in cases of widespread infiltrating brain lesions when the clinical features are atypical or unexpected, and to consider brain biopsy in those cases.

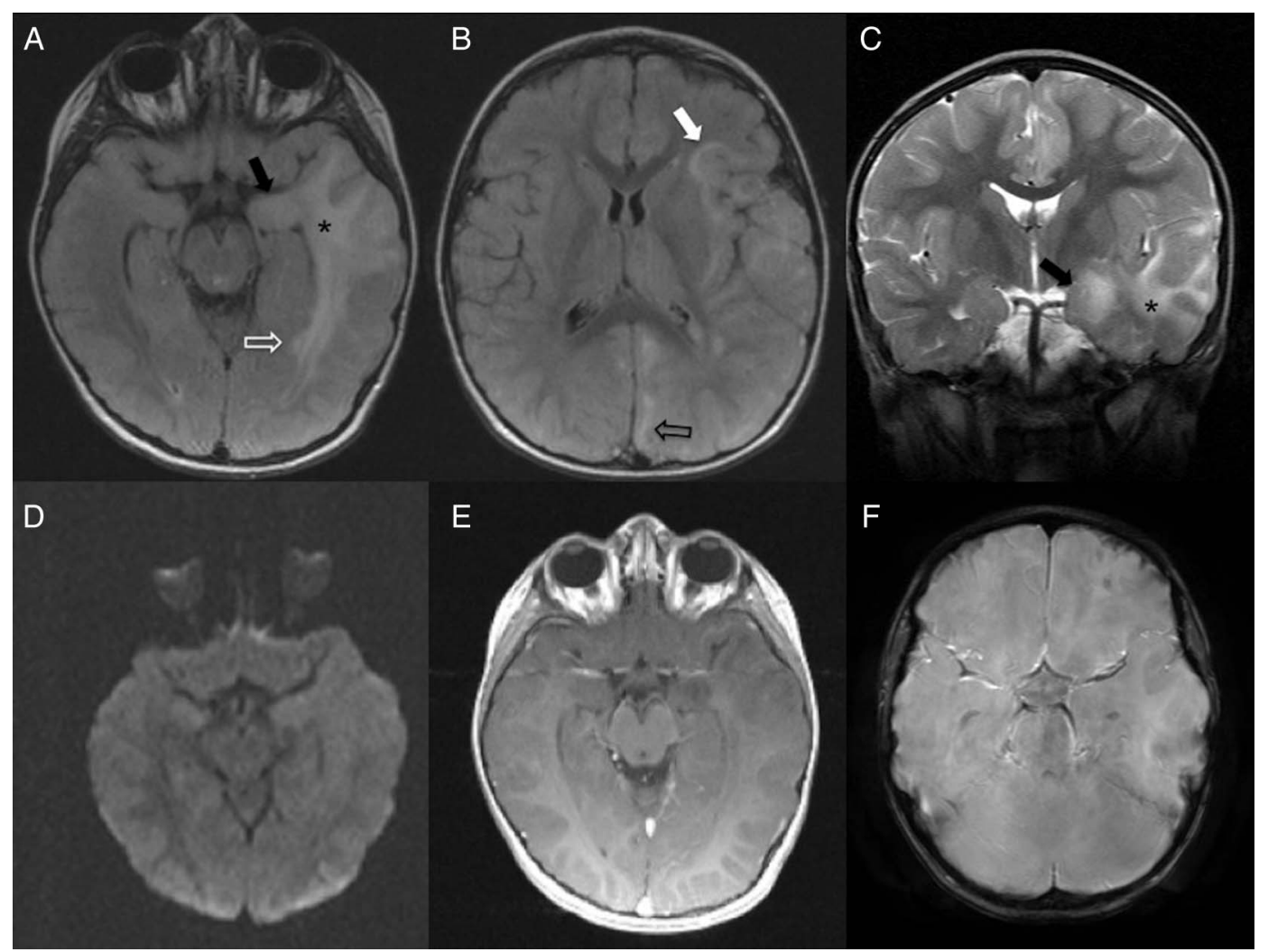

Figure 1 Axial fluid attenuated inversion recovery (A and B) and coronal T2-weighted (C) MRI obtained at initial presentation demonstrate an extensive, hyperintense abnormality centred on the white matter of the left temporal lobe (asterisk) and extending into the white matter of the left frontal lobe (white arrow) and left parietal lobe (open white arrow). The cortex of the left mesial temporal lobe (black arrow) and left parasagittal occipital lobe (open black arrow) are also involved. Diffusion-weighted imaging (D) does not demonstrate diffusion restriction in the lesion. Postcontrast T1-weighted MR sequence (E) does not demonstrate enhancement. There is no microhaemorrhage on susceptibility-weighted SWAN sequence (F). 


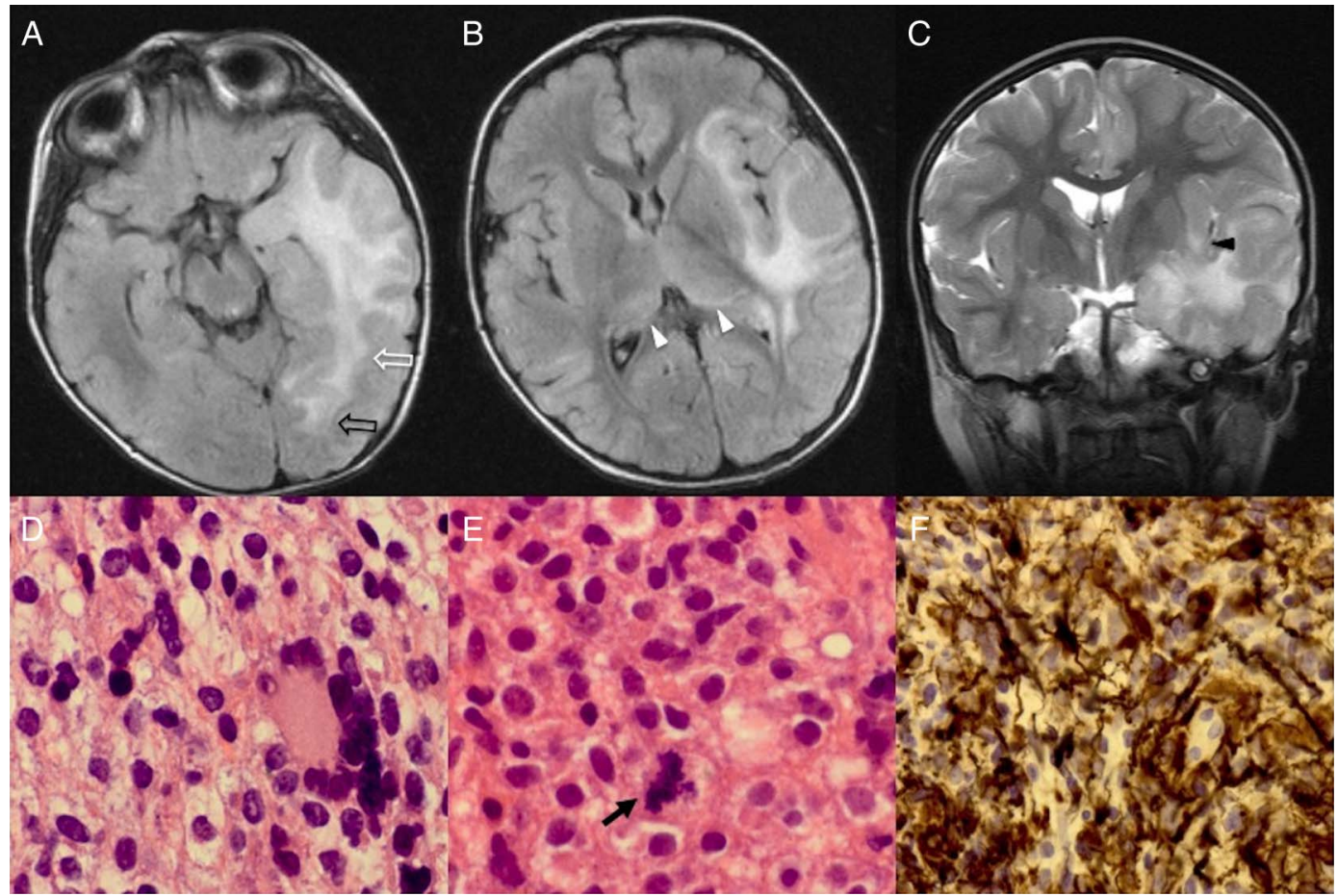

Figure 2 Axial fluid attenuated inversion recovery (A and B) and coronal T2-weighted (C) MRI performed 4 weeks from initial presentation. There has been significant progression of the lesion, with extension into the left parietal lobe (open white arrow), left occipital lobe (open black arrow), both thalami (white arrow heads) and left insular cortex (black arrow head). White matter biopsy ( $D$ and E; H\&E stain, original magnification $\times 600$ ) demonstrates pleomorphic astrocytes and multiple mitotic figures (black arrow). Immunohistochemical staining ( $F$; original magnification $\times 400$ ) demonstrates expression of glial fibrillar acidic protein. Histopathology is consistent with WHO grade III anaplastic astrocytoma.

\section{Learning points}

- Gliomatosis cerebri is an infiltrating glial tumour, which is rare in children.

- Appearance on MRI is typically of a contiguous, fluid attenuated inversion recovery hyperintense abnormality involving at least three cortical lobes with diffuse mass effect.

- It presents with non-specific symptoms and signs and may mimic more common disorders, such as infectious encephalitis and acute disseminated encephalomyelitis.

Contributors MWM drafted and revised the manuscript. MAM contributed clinical details of the case. SL critically revised the manuscript. MK critically revised the manuscript and approved the final draft.

\section{Competing interests None.}

Patient consent Obtained.

Provenance and peer review Not commissioned; externally peer reviewed.

\section{REFERENCES}

1 Armstrong GT, Phillips PC, Rorke-Adams L, et al. Gliomatosis cerebri: 20 years of experience at the Children's Hospital of Philadelphia. Cancer 2006;107:1597-606.

2 Chappe C, Riffaud L, Treguier C, et al. Primary gliomatosis cerebri involving gray matter in pediatrics: a distinct entity? A multicenter study of 14 cases. Childs Nerv Syst 2013;29:565-71.

3 Maton B, Resnick T, Jayakar P, et al. Epilepsy surgery in children with gliomatosis cerebri. Epilepsia 2007:48:1485-90.

4 Harrison JF, Richard HT, Abel TW, et al. Gliomatosis cerebri: report of 3 cases. J Neurosurg Pediatr 2010;6:291-4.

5 Richard HT, Harrison JF, Abel TW, et al. Pediatric gliomatosis cerebri mimicking acute disseminated encephalomyelitis. Pediatrics 2010;26:479-82.

Copyright 2014 BMJ Publishing Group. All rights reserved. For permission to reuse any of this content visit

http://group.bmj.com/group/rights-licensing/permissions.

BMJ Case Report Fellows may re-use this article for personal use and teaching without any further permission.

Become a Fellow of BMJ Case Reports today and you can:

- Submit as many cases as you like

- Enjoy fast sympathetic peer review and rapid publication of accepted articles

- Access all the published articles

- Re-use any of the published material for personal use and teaching without further permission

For information on Institutional Fellowships contact consortiasales@bmjgroup.com

Visit casereports.bmj.com for more articles like this and to become a Fellow 